\title{
Alternative Bedding Materials for Poultry: Availability, Efficacy, and Major Constraints
}

\author{
Siaka Diarra*, Sonny Lameta, Falaniko Amosa and Sanjay Anand \\ School of Agriculture, Geography, Environment, Ocean and Natural Sciences, The University of the South Pacific, \\ Apia, Samoa
}

\section{OPEN ACCESS}

Edited by:

Laura Ann Boyle,

Teagasc Food Research

Centre, Ireland

Reviewed by:

Jen-Yun Chou,

University of Pennsylvania,

United States

Henry Allen Torbert,

United State Department of

Agriculture, United States

*Correspondence:

Siaka Diarra

siaka.diarra@samoa.usp.ac.fj

Specialty section:

This article was submitted to Animal Behavior and Welfare,

a section of the journal

Frontiers in Veterinary Science

Received: 01 March 2021

Accepted: 14 July 2021

Published: 17 August 2021

Citation:

Diarra S, Lameta S, Amosa F and Anand S (2021) Alternative Bedding Materials for Poultry: Availability, Efficacy, and Major Constraints.

Front. Vet. Sci. 8:669504. doi: 10.3389/fvets.2021.669504
The increasing demand of wood shavings (WS) and sawdust (SD) by other industries and growing concerns of potential chemical contaminants from wood products have amplified research interest in alternative bedding materials for commercial poultry. Several alternative materials - corn cob (CC), straws (ST) and hays (HA), sand (SA), shredded papers (SP), rice hulls $(\mathrm{RH})$, peanut hulls $(\mathrm{PH})$, and gypsum $\left(\mathrm{CaSO}_{4} .2 \mathrm{H}_{2} \mathrm{O}_{2}\right)$ - can replace conventional ones in poultry houses, depending on availability, cost, and ability to absorb and adsorb moisture and provide the birds enough room to exhibit their natural behaviors. Alternative materials hold a brighter future as bedding materials, but more studies about their physicochemical properties and litter management practices for optimum poultry welfare are recommended.

Keywords: bedding material, bird welfare, housing systems, product quality, poultry production

\section{INTRODUCTION}

Globally, the poultry industry is witnessing a rapid growth to meet the demand of the everincreasing world population with higher income and better food choices $(1,2)$. While commercial layers may still be found in cages, broilers are almost always raised on litter. The rapid growth rate in broiler production (1) and the gradual ban of the cage system for layers will mean more litter materials for the poultry industry. Several factors including unavailability, increasing cost, and possible health and safety risks of conventional materials have been the major forces driving research into new bedding materials for commercial poultry. Wood shavings (WS) and sawdust (SD) are becoming scarce and expensive (3-5) due to their increasing use for highway construction (6-8), lightweight concretes (9-12), and heating and roofing felts $(5,13)$.

The past decades have seen increased research in alternative litter materials for poultry (14). Several alternatives to wood by-products have been used with varying outcomes on bird welfare and performance. In view of differences in the availability of substrates used for bedding materials among regions, reviews summarizing the characteristics of alternative materials, their effectiveness, and major issues would benefit the poultry industry. This paper reviews the availability, efficacy, and major issues in the use of selected alternative bedding materials in commercial poultry houses.

\section{SOME ATTRIBUTES OF LITTER MATERIALS}

For a product to qualify as litter material, it must be readily available, cheap, absorbent, and free from dust and contaminants; must have low thermal conductivity; and should not cake or compact. The type of bedding material exerts direct effects on productive performance $(15,16)$, health $(17,18)$, product quality (carcass and eggs), and poultry welfare $(14,15,19,20)$. 
A good litter material should be able to absorb and release moisture to the environment as quickly as possible (4). Several chemical characteristics including the cellulose, silica, and lignin contents influence the quality of litter materials. Cellulose and silica are capable of absorbing water due to their high hydrophilic groups and higher surface area due to smaller particle size (2123), respectively. The initial moisture content is also an important factor to consider in the choice of any bedding material. High moisture in the bedding increases ammonia build-up through increased microbial metabolism, resulting in respiratory and eye lesions $(20,24)$, which adversely affect birds' welfare and productivity (25). Wet litter predisposes to breast blisters and hock burns $(25,26)$, which reduce carcass quality in meat birds. Litter moisture (27-29) and source may also encourage the multiplication of Salmonella, Campylobacter, and Listeria spp. and Eimeria spp., the causative agent of coccidiosis (18). In addition to bird health and product quality, nitrogen $(\mathrm{N})$ loss through ammonia volatilization is a major air pollutant with severe environmental health consequences (30).

Because poultry may consume a significant proportion (as much as $4 \%)$ of their feed in litter $(15,17)$ or forage directly on the litter material $(1,31,32)$, the bedding substrate must be free from possible contaminants that could be taken up in the tissues. Chemical preservatives have been major criticisms to the use of WS and SD as bedding materials. Common wood preservatives such as sodium borate and copper chrome arsenate (C.C.A.), may be retained in the tissue, posing health risks to the human consumer of poultry products (1). As a measure to minimize this risk, many countries in Europe (France, Ireland, England, and Denmark) are now producing untreated softwood shavings as bedding material for the intensive livestock and poultry industries (1). Using suitable litter materials, stocking density and litter management practices have the greatest influence on poultry behavior, welfare, and productivity $(33,34)$. The quality of the litter is determined by the litter moisture, $\mathrm{pH}$, ammonium nitrate content, caking level, and water holding capacity (35).

Dustiness from extremely dry bedding materials (17) or very fine particles (15) may predispose birds to respiratory problems, resulting in higher mortality. Very large and coarse bedding materials may, however, downgrade carcass quality due to their abrasive effects $(20,36)$. From the foregoing discussion, several characteristics of the bedding material affect poultry welfare, productivity, and product quality.

\section{AVAILABILITY OF SELECTED ALTERNATIVE BEDDING MATERIALS FOR POULTRY}

\section{Rice Hulls}

Rice hull $(\mathrm{RH})$ is an important by-product of the rice milling process, representing about $25 \%$ of rice paddy $(37,38)$. This will translate to about 179 million tons of hulls from the estimated 715 million tons of paddy produced globally per year (38). $\mathrm{RH}$ is still a waste in many regions, posing disposal problems, and this has increased research interest in alternative uses. $\mathrm{RH}$ is burnt onsite to provide energy for mechanical rice milling, used in the ceramic and construction industries $(39,40)$ or livestock and poultry feeding, but its high silica and lignin contents (41) limit its full utilization as feed, making it available as bedding material in many rice-growing regions.

\section{Corn Cob}

Corn or maize (Zea mays) is the most important cereal with the global production estimated at about 875 million tons (42). Corn cob (CC), a by-product of corn processing for grain, accounts for $180-200 \mathrm{~kg}$ per ton of grains produced (43). Currently, this residue has a number of limited applications including building material and activated carbon $(44,45)$ and still regarded as waste in many producing regions, posing environmental problems (46). CC has high holo-cellulose (cellulose and hemicellulose) and low lignin contents (47). The ready availability and high absorbency $(4,26)$ make CC a potential litter material for poultry.

\section{Sand}

The annual global consumption of sand (SA) is estimated to be 15 billion tons (48). Sand is increasingly used by several industries, including the building industry (houses and roads), electronics (computer chips and microprocessors), cosmetics, and detergents, among others. River sand is clean and has high water absorbing capacity but desert sand is too fine and smooth, high in clay, iron oxides, and lime but lacks silicon dioxide $(4,49,50)$, making the former a better litter material than the latter. The poor absorbency of desert sand and the increasing demand of river sand for bedding and the construction industry may, however, exacerbate the already existing environmental consequences of sand mining $(48,51)$.

\section{Straws/Hays}

Straw (ST) is the fibrous residue from grain crop harvest. As the global production of cereals such as rice, wheat, and barley continues to increase, ST from the harvest of these crops become readily available. ST are, however, high in lignin (52) and low in hydrophilic groups (53), which reduce their ability to absorb and release moisture. Hay (HA) from grasses, although lower in lignin compared to ST, is also not very absorbent probably due the relatively high initial moisture content in cured HA (10-15\%). Straw and HA beddings may therefore compact rapidly, predisposing birds to fungal infection and increasing the incidence of breast blisters. Where ST and HA are cheap, however, they may be used as bedding materials to save cost, provided the litter is renewed regularly. The ease to compost ST could be an environmental incentive as this will reduce disposal problems of straw-based bedding materials.

\section{Sugar Cane Bagasse}

Sugar cane bagasse (SCB), a by-product of sugar refining, amounts to about $140 \mathrm{~kg}$ per ton of sugar cane processed (54). SCB has high water absorbing ability due to its residual sugar content. However, SCB cakes easily (55), and this calls for more research to improve its utilization as bedding material for poultry.

\section{Shredded Newspapers}

Newspapers have long been used as animal bedding. Despite the rapid adoption of soft copies, papers are available (3) and 
may pose disposal problems (56). Paper is absorbent, is easy to decompose (57), and has minimal health risks (free from dust, contaminants, and pathogenic organisms), but does not release moisture to the environment as quickly as possible. Processing newspapers into chips improves its moisture holding capacity and evaporative loss (58). However, the growing trend of the paper recycling industry may not spare this for use as economic bedding material. Paper recycling increased from 5 million tons in 1960 to 44 million tons in 2017 (48). Consumption of newspapers printed with inks based on petroleum-laden or heavy metals $(59,60)$ may, however, pose health concerns.

\section{Peanut Hulls}

Globally, peanut (Arachis hypogaea) occupies, on average, 22.2 million hectares, with a share of 16.3 million hectares, 7.39 million hectares, and 0.7 million hectares in Asia, Africa, and South and Central America, respectively (61). Peanut yield ranges from 3 to 4 ton/ha, but yields as high as 9.6 tons/ha have been reported (62). Global peanut production was estimated at 40 million tons in 2015 (63). With the estimated 25\% hull $(64,65)$, this will amount to about 10 million tons of peanut hull $(\mathrm{PH})$ consisting of variable amount of broken kernels. In most peanutproducing countries, the hulls are burned on farm, dumped, or allowed to deteriorate naturally (66), making this by-product readily available for various uses.

\section{Gypsum}

Gypsum $\left(\mathrm{CaSO}_{4} 2 \mathrm{H}_{2} \mathrm{O}_{2}\right)$ is a carbonaceous material used in the wallboard and cement industries as well as for agricultural production. However, global gypsum production is reported to exceed the capacity of these industries (67). This has increased research into alternative uses for gypsum to minimize problems of storage and disposal. Because of its ability to absorb moisture and reduce litter $\mathrm{pH}$, the application of gypsum in litter amendment has been receiving research attention.

\section{SUMMARY OF THE APPLICATION OF SOME ALTERNATIVE MATERIALS}

\section{Bedding Material and Litter Quality}

There is sufficient literature on the effect of bedding substrate on litter quality. Benabdeljelil and Ayachi (16) evaluated whole and ground wheat straw (WHS), ground rice straw (RS), RH, $\mathrm{SD}$, and WS singly or in combinations in Warren cockerel chicks and found no effect on water consumption, but litter moisture, temperature, $\mathrm{pH}$, and overall quality score were reduced on straw-based litters compared to the other materials. The authors attributed this to the low water holding capacity (WHC) of the straw-based litters due to the high lignification of straw. The insolubility of lignin is mainly due to its compact nature, low molecular weight, and fewer hydrophilic groups (53). In another report, Diarra et al. (68) found no differences between WS and whole or chopped Para grass (Brachiaria mutica) hay in terms of moisture retention and litter caking in Shaver brown laying hens. Grimes et al. (69) also observed that chopping improved the efficacy of straw as a bedding material and concluded that particle size rather than type of material is an important factor of litter quality. The effect of particle size of fibrous materials on WHC is well-documented $(52,70,71)$. Grasses for hay production are normally harvested at relatively younger age with lower lignin content compared to straw. Low lignification and high cellulose content may explain the higher WHC of hay. It follows, therefore, that grasses used for bedding should be harvested when the ratio cellulose/lignin is still high. However, as cured hay may contain up to $20 \%$ moisture $(72,73)$, this initial moisture content will affect its ability to absorb moisture for a longer period, but needs more investigation. In a study comparing different bedding materials (WS, SA, RH, grass, SP, and CC) for broilers, Garcês et al. (4) found no difference in water-releasing capacity among the materials during the first $24 \mathrm{~h}$, but the ability of WS, RH, grass, and SP to lose water reduced by about $34 \%$ thereafter. This suggests that the duration of rearing and birds' age are important considerations in assessing the quality of a bedding material for poultry. CC and SA litters had the lowest moisture content at the conclusion of the experiment. The ability of CC to absorb and lose water has been attributed to its higher content of cellulose and hemicellulose and lower lignin (74). The high water absorption capacity of sand has been attributed to its coarse particle sizes, which release water faster and keep the surface dry (4). Contrary to these findings, however, Shields et al. (26) observed no differences in litter moisture content and temperature between SA and WS. Gypsum is reported to reduce litter $\mathrm{NH}_{3}$ content (75-77), which could improve the welfare of birds. Several factors including litter depth, relative humidity, and bird stocking density might be possible reasons of variation among studies. The relative humidity greatly affects the ability of a bedding material to lose water to the environment. Weaver and Meijerhof (78) observed increased litter caking, moisture, and ammonia contents with increasing relative humidity from 45 to $75 \%$ in environmentally controlled broiler houses.

\section{Bedding Materials and Poultry Welfare and Performance}

The quality of bedding materials has the greatest influence on ammonia production, which adversely affects the performance of birds. Studies have shown that high levels of ammonia in the house decrease the efficiency of feed utilization, weight gain, and egg production (79-83). The mode of action of ammonia on poultry performance is directly related to its damaging effect on the respiratory tissues (84) and impairment of the bird's immune response (85). Microbial activity on wet litters (8689 ) is a major factor in ammonia production in the house. It is therefore evident that the quality of the bedding material, mainly its ability to absorb moisture, is important in maintaining a healthy house environment and better performance of poultry. As different bedding substrates produce different conditions in the poultry house $(20,26,90)$, choosing the right litter materials is important for maximum poultry welfare and productivity. Because litter moisture is an important factor encouraging the multiplication of pathogenic organisms (27-29, 88), it follows that bedding materials with low WHC would quickly predispose to disease outbreak. 
Benabdeljelil and Ayachi (16) observed no effects of whole and ground WHS, ground rice straw (RS), RH, SD, and WS or their combinations on growth, water consumption, and mortality rate in Warren cockerel chicks, but litter ammonia content was increased on straw, probably due to its low WHC earlier mentioned. Monira et al. (91) observed improved body weight gain (BWG), feed consumption, and survivability in broilers raised on SD compared to birds on $\mathrm{RH}, \mathrm{SCB}$, and WHS beddings. Contrary to these findings, Toghyani et al. (92) found no effects of WS, RH, paper roll (PR), and sand on feed intake, feed conversion, and mortality of broilers, but BWG and antibody titer against Newcastle disease reduced on RH. The authors attributed this to possible higher pathogenic bacterial count on $\mathrm{RH}$ compared to the other materials. Munir et al. (93) also confirmed lower count of enteric bacteria on sand compared to organic materials due mainly to differences in nutrient availability and lack of binding site for bacteria in sand.

Nowaczewski et al. (94) reported better BWG, foot health, feed conversion ratio, hemoglobin saturation, and lower mortality rates on WS compared to whole or chopped WHS beddings. Several studies $(4,26,74)$ found no difference in ammonia content between WS, CC, and SA litters in broilers. Sand bedding may also improve bird welfare through increased behavioral performance $(26,74)$. Given the choice, broilers showed preference for SA to WS $(20,26,74)$ or RH, chopped Napier grass, and SCB (20) in terms of performance and natural behaviors. Diarra et al. (68) also found no differences between WS and whole or chopped Para grass hay on egg performance and litter caking in laying hens, but chopping the hay reduced the incidence of feather pecking, probably due to the inability of the birds to forage efficiently on larger particle sizes. Several factors including the class and age of the bird, stocking density, litter processing, and thickness all affect the suitability of a material as bedding substrate. Higher stocking densities reduce litter quality and bird welfare $(25,95)$ and bird performance $(96,97)$ due to higher excreta output and rapid deterioration of the bedding material. Shao et al. (98) also observed an improved welfare and production of broiler chickens with increasing thickness of SD-based beddings from 4 to $16 \mathrm{~cm}$. These findings suggest that increasing stocking density must be accompanied by corresponding increases in litter depth.

Ramadan et al. (5) found no effects of WS, whole RS, and SA singly or in combinations on carcass weight and welfare indices (fear, developmental instability, feather score, footpad dermatitis, and stress) of broilers, but BWG improved on SA-based litters. Gizzard weight increased on WS compared to SA or RS beddings. The improved weight gains on SA or mixtures containing it may be attributed to better welfare, further elucidating the quality of SA as bedding material. The authors attributed the pattern of gizzard development to (i) increased activity of this organ due to consumption of the fibrous shavings, (ii) faster rate of passage of SA through the gastrointestinal tract, and (iii) difficulty in consuming RS compared to WS.

The use of PH as litter material is well-documented (58, 99, 100). Lien et al. (58) found no differences in litter $\mathrm{pH}, \mathrm{BWG}$, feed consumption, mortality, and flock uniformity of broiler breeder pullets raised on $\mathrm{PH}$ and fine WS from 11 weeks of age, but gizzard weight increased on WS than $\mathrm{PH}$. The authors attributed this to litter consumption and differences in fiber content between the litter sources. According to Jones et al. (99), aflatoxin contamination can be a major problem in birds reared on $\mathrm{PH}$ in early life, but the addition of moisture and fecal materials to the bedding with age or aflatoxin breakdown by ammonia will overcome this. These observations suggest the need for more research in stocking densities, which will produce maximum dropping on $\mathrm{PH}$ in early life. Using SA, WS, and SP as litter material had no marked effects on broiler performance but treatment with bentonite reduced litter moisture content (101) due to high ability of bentonite to absorb moisture. Where materials with low moisture absorbing capacity are readily available, litter treatment can be a viable option.

The mode of action of gypsum on $\mathrm{NH}_{3}$ production is not clear but probably by inactivation of $\mathrm{NH}_{3}$-producing bacteria through absorption of litter moisture content causing osmotic stress (102) and reduction in litter $\mathrm{pH}$ (103). In a 49-day growth experiment, Sampaio et al. (104) observed a significant reduction of bacterial count in broiler litter amended with gypsum. Oliveira et al. (103) reported $\mathrm{NH}_{3}$ reduction in broiler litter treated with $40 \%$ gypsum. In another study, addition of gypsum to broiler litter at 10 and $20 \%$ reduced its $\mathrm{NH}_{3}$ content by $21 \%$ (76). These results suggest that several factors may affect the efficacy of gypsum as litter material. Phosphorus emission from poultry litter, another environmental concern, is also reported to be minimized by gypsum application (67). The effect of gypsum-treated litter on live performance is not consistent. Grimes et al. (105) observed no effect of a mixture of gypsum, cotton waste, and old newspapers on the growth performance of broilers and turkeys. Wyatt and Godman (106) reported a significantly lower body weight in broilers raised on recycled wallboard gypsum compared to the control based on wood shavings. Several factors including the source of primary bedding material, litter depth, and application rate of gypsum may all affect the performance of poultry. This calls for the need to do more research in the application of gypsum as bedding material for poultry. Table 1 summarizes the efficacy of selected materials as bedding substrates in poultry houses and the major issues.

\section{Some Nutritional and Environmental Factors Affecting Litter Quality}

Several nutritional and environmental factors may also influence litter quality and bird performance. Diet composition and physicochemical characteristics are known to influence litter quality in birds kept on the same bedding substrate $(43,110-$ 113). Viscous fibers in the diet reduce nutrient digestion and absorption $(111,112,114)$ and increase cecal fermentation (115, 116). Increased fermentation in the cecum resulting in soft feces is a major cause of wet litter in poultry houses (110). This suggests the need to increase litter depth to cope with excessive moisture in the excreta of birds fed high viscous fiber diets. Several salts including $\mathrm{NaCl}$ and $\mathrm{KCl}$, which are added to the feed and water as a means of combatting heat stress, would also increase excreta output and litter moisture (117). High humidity 
TABLE 1 | Summary of the potential and constraints of selected substrates as litter materials for poultry.

\begin{tabular}{|c|c|c|c|}
\hline Material & Potential & Constraints & References \\
\hline Wood shavings & $\begin{array}{l}\text { Conventional litter material, highly absorbent, and } \\
\text { adsorbent. Improves welfare through dustbathing } \\
\text { and foraging. }\end{array}$ & $\begin{array}{l}\text { Expensive due to competition among several } \\
\text { industries. Potential risks of contamination from } \\
\text { chemically treated woods. }\end{array}$ & $(1,6)$ \\
\hline Sawdust & $\begin{array}{l}\text { Absorbent and improves welfare through } \\
\text { dustbathing and foraging. }\end{array}$ & $\begin{array}{l}\text { Competition with other industries, low ability to } \\
\text { release moisture and frequent caking. Fine } \\
\text { particles may predispose to respiratory } \\
\text { problems. Risks of chemical preservatives. }\end{array}$ & $(56,107)$ \\
\hline Straw & $\begin{array}{l}\text { Readily available and cheap. Chopping improves } \\
\text { water holding capacity and provides for foraging. }\end{array}$ & $\begin{array}{l}\text { Low water holding capacity due to lignin content } \\
\text { and risk of caking. }\end{array}$ & $(52,55,69)$ \\
\hline Sand & $\begin{array}{l}\text { Readily available. Coastal sand absorbent and } \\
\text { adsorbent. Clean bedding with no risk of caking. } \\
\text { Maximizes bird welfare through dustbathing. }\end{array}$ & $\begin{array}{l}\text { Environmental consequences of sand mining. } \\
\text { Desert sand has poor absorbency. }\end{array}$ & $(4,26,74)$ \\
\hline Corn cob & $\begin{array}{l}\text { Readily available during corn harvest. Absorbent } \\
\text { and adsorbent. Reduces litter ammonia content } \\
\text { and improves bird welfare and productivity. }\end{array}$ & $\begin{array}{l}\text { Energy cost of crushing corn cob. } \\
\text { Future competition due to increasing use as } \\
\text { ruminant feed. }\end{array}$ & $(4,26)$ \\
\hline Rice husk & $\begin{array}{l}\text { Available and cheap. Reduces the incidence of } \\
\text { footpad dermatitis and breast blisters. }\end{array}$ & May easily compact. & $(4,18,101)$ \\
\hline Shredded newspapers & $\begin{array}{l}\text { Readily available and cheap from paper } \\
\text { industries. }\end{array}$ & $\begin{array}{l}\text { Low absorbency. Easily cakes and causes breast } \\
\text { blisters. }\end{array}$ & $(55,56)$ \\
\hline Sugar cane bagasse & $\begin{array}{l}\text { Readily available from sugar industries. } \\
\text { Absorbent and adsorbent. }\end{array}$ & May cake and cause breast blisters. & $(55)$ \\
\hline Corn silage & Reduces the incidence of salmonella. & Competition with the ruminant industry. & $(108)$ \\
\hline Coconut husk & Readily available and cheap. & Low water holding capacity & (4) \\
\hline Peanut hull (shell) & $\begin{array}{l}\text { Readily available and may pose environmental } \\
\text { problems. Comparable to shavings as litter } \\
\text { material. }\end{array}$ & Risk of aflatoxin contamination. & $(58,64,100,109)$ \\
\hline Gypsum & $\begin{array}{l}\text { Readily available, cheap and absorbent. Reduces } \\
\text { bacterial load, } \mathrm{NH}_{3} \text {, and phosphorus emissions }\end{array}$ & May have no beneficial effects on growth. & $(67,76,102,106)$ \\
\hline
\end{tabular}

in the air also reduces the ability of the bedding material to lose moisture to the environment and adversely affects poultry performance. Weaver and Meijerhof reported higher BWG and drier moisture in broiler chickens at $45 \%$ compared to those kept at $75 \%$ relative humidity.

\section{CONCLUSIONS}

Wood-based materials, the traditional litter materials in many regions, are becoming short in supply or criticized due to growing concerns of potential chemical contaminants. Several materials including newspapers, CC, sand, RHs, peanut shell, and gypsum can be suitable alternatives to wood-based beddings in poultry houses. The source, texture, and particle size of the material; litter depth; age and class of bird; duration of rearing; diet composition; stocking density; and relative humidity all affect

\section{REFERENCES}

1. Embury IS. Alternative Litter Materials for Poultry. (2004) Available online at: https://www.dpi.nsw.gov.au/_data/assets/pdf_file/0004/134446/ Alternative-litter-materials-for-poultry.pdf (accessed January 13, 2021).

2. Plantz B. New Look for WATT Executive Guide to World Poultry Trends. (2013) Available online at: https://www.wattagnet.com/articles/17177-new- the suitability of a material as litter. There is a need for more research on litter management practices and cost-effectiveness of different materials for optimum bird welfare, productivity, and product quality.

\section{AUTHOR CONTRIBUTIONS}

SD: conception, investigation, methodology, writing-original draft and writing - review and editing. SL, FA, and SA: writingreview and editing. All authors contributed to the article and approved the submitted version.

\section{ACKNOWLEDGMENTS}

Authors acknowlege the University of the South Pacific for paying the publication fee. look-for-watt-executive-guide-to-world-poultry-trends (Accessed January 13, 2021).

3. Davis JD, Purswell J, Columbus EP, Kiess A. Evaluation of chopped switchgrass as a litter material. Int J Poult Sci. (2010) 9. doi: $10.3923 /$ ijps.2010.39.42

4. Garcês A, Afonso SMS, Chilundo A, Jairoce CTS. Evaluation of different litter materials for broiler production in a hot and humid environment: 
1. litter characteristics and quality. J Appl Poultry Res. (2013) 22:16876. doi: 10.3382 /japr.2012-00547

5. Ramadan SG, Mahboub HD, Helal MA, Gaafar KM. Behaviour, welfare and performance of broiler chicks reared on different litter materials. Assiut Vet Med J. (2013) 59:9-18. doi: 10.21608/avmj.2013.171599

6. Charles EB. Litter Management for Confined Turkeys. Charlotte, NC: The North Carolina Agricultural Extension Service (2005).

7. Labelle ER, Jaeger D. Soil compaction caused by cut-to-length forest operations and possible short-term natural rehabilitation of soil density. Soil Sci Soc Am J. (2011) 75:2314-29. doi: 10.2136/sssaj2011.0109

8. Hruza P, Pelikán P, Blahuta J, Nedorost J, Patočka Z. A structural reinforcement layer with woodchips used on forest roads. Nova mehanizacija šumarstva. (2016) 37:25-34. Available online at: https://hrcak.srce.hr/17380I

9. Walter H, Walter-Gurzeler LM. Coated Free Aggregate Usable in Wood Concrete Technology and Method of Making the Same. (1991) Available online at: https://patents.google.com/patent/US5019170A/en (accessed January 13, 2021).

10. Xing Z, Djelal C, Vanhove Y, Kada H. Wood waste in concrete blocks made by vibrocompression. Environ Process. (2015) 2:223-32. doi: 10.1007/s40710-015-0104-4

11. Osei D, Jackson E. Compressive strength of concrete using sawdust as aggregate. Int J Sci Eng Res. (2016) 7:1349-53.

12. Okoroafor S, Onukwugha O, Onukwugha E, Anyaogu L, Adah E. Structural characteristics of sawdust-sand-cement composite. Int J Adv Res Technol. (2017) 6:173-80.

13. Sikkema R, Steiner M, Junginger M, Hiegl W, Hansen MT, Faaij A. The European wood pellet markets: current status and prospects for 2020. Biofuels Bioproducts Biorefining. (2011) 5:250-78. doi: 10.1002/ bbb. 277

14. Almeida Paz ICL, Garcia RG, Bernardi R, Nääs IA, Caldara FR, Freitas LW, et al. Selecting appropriate bedding to reduce locomotion problems in broilers. Brazil J Poultry Sci. (2010) 12:189-95. doi: 10.1590/S1516-635X2010000300008

15. Malone GW, Chaloupka GW, Saylor WW. Influence of litter type and size on broiler performance: 1. factors affecting litter consumption1. Poult Sci. (1983) 62:1741-6. doi: 10.3382/ps.0621741

16. Benabdeljelil K, Ayachi A. Evaluation of alternative litter materials for poultry. J Appl Poultry Res. (1996) 5:203-9. doi: 10.1093/japr/5.3.203

17. Torok VA, Hughes RJ, Ophel-Keller K, Ali M, Macalpine R. Influence of different litter materials on cecal microbiota colonization in broiler chickens. Poult Sci. (2009) 88:2474-81. doi: 10.3382/ps.2008-00381

18. Sheffield CL, Crippen TL, Beier RC. Multi-microbial compounds eliminate or reduce Salmonella Typhimurium from one-third of poultry liter samples within 8 days. Res J Poultry Sci. (2018) 11:5-8. doi: $10.36478 /$ rjpscience.2018.5.8

19. Ngajilo D, Singh T, Ratshikhopha E, Dayal P, Matuka O, Baatjies R, et al. Risk factors associated with allergic sensitization and asthma phenotypes among poultry farm workers. Am J Ind Med. (2018) 61:51523. doi: 10.1002/ajim.22841

20. Garcia R, Paz ICLA, Caldara FR, Nääs IA, Bueno L, Freitas L, et al. Litter materials and the incidence of carcass lesions in broilers chickens. Braz J Poultry Sci. (2012) 14:27-32. doi: 10.1590/S1516-635X20120001 00005

21. Heiner AP, Teleman O. Interface between monoclinic crystalline cellulose and water: breakdown of the odd/even duplicity. Langmuir. (1997) 13:5118. doi: 10.1021/la960886d

22. Chami Khazraji A, Robert S. Self-assembly and intermolecular forces when cellulose and water interact using molecular modeling. J Nanomater. (2013) 2013:e745979. doi: 10.1155/2013/745979

23. Lindh EL. Cellulose-Water Interaction: A Spectroscopic Study. (2016). Available online at: http://urn.kb.se/resolve?urn=urn:nbn:se:kth:diva199200 (accessed June 19, 2021).

24. Traldi AB, Oliveira MC de, Duarte KF, Moraes VMB de. Avaliação de probióticos na dieta de frangos de corte criados em cama nova ou reutilizada. Revista Brasileira de Zootecnia. (2007) 36:660-5. doi: 10.1590/S1516-35982007000300020

25. Ferrante V, Lolli S, Marelli S, Vezzoli G, Sirri F, Cavalchini LG. Effect of light programmes, bird densities and litter types on broilers welfare.
In: EPC 2006 - 12th European Poultry Conference, Verona, Italy, 1014 September, 2006. (2006) Available online at: https://www.cabdirect.org/ cabdirect/abstract/20093210273 (accessed January 12, 2021)

26. Shields SJ, Garner JP, Mench JA. Effect of sand and wood-shavings bedding on the behavior of broiler chickens. Poult Sci. (2005) 84:181624. doi: $10.1093 / \mathrm{ps} / 84.12 .1816$

27. Carr LE, Mallinson ET, Tate CR, Miller RG, Russek-Cohen E, Stewart LE, et al. Prevalence of salmonella in broiler flocks: effect of litter water activity, house construction, and watering devices. Avian Dis. (1995) 39:3944. doi: $10.2307 / 1591980$

28. Chinivasagam HN, Redding M, Runge G, Blackall PJ. Presence and incidence of food-borne pathogens in Australian chicken litter. Br Poult Sci. (2010) 51:311-8. doi: 10.1080/00071668.2010.499424

29. Wilkinson KG, Tee E, Tomkins RB, Hepworth G, Premier R. Effect of heating and aging of poultry litter on the persistence of enteric bacteria. Poult Sci. (2011) 90:10-8. doi: 10.3382/ps.2010-01023

30. Adeli A, Tewolde H, Sistani KR, Rowe DE. Broiler litter fertilization and cropping system impacts on soil properties. Agron J. (2009) 101:130410. doi: 10.2134/agronj2009.0150

31. Steenfeldt S, Engberg RG, Kjær J. Feeding roughage to laying hens affects egg production, gastrointestinal parameters and mortality. In: Feeding Roughage to Laying Hens Affects Egg Production, Gastrointestinal Parameters and Mortality. Belgium: Blankenberge (2001). p. 238-9.

32. Diarra SS. Poultry industries in the South Pacific region: issues and future direction. World's Poultry Sci J. (2017) 73:293-300. doi: 10.1017/S0043933916001070

33. Huang Y, Yoo JS, Kim HJ, Wang Y, Chen YJ, Cho JH, et al. Effect of bedding types and different nutrient densities on growth performance, visceral organ weight, and blood characteristics in broiler chickens. J Appl Poultry Res. (2009) 18:1-7. doi: 10.3382/japr.2007-00069

34. Kaukonen E, Norring M, Valros A. Evaluating the effects of bedding materials and elevated platforms on contact dermatitis and plumage cleanliness of commercial broilers and on litter condition in broiler houses. Br Poult Sci. (2017) 58:480-9. doi: 10.1080/00071668.2017.1340588

35. Gençoglan S, Gençoglan C. The effect of the litter materials on broiler chickens welfare and performance. Turkish J Agric Food Sci Technol. (2017) 5:1660-7. doi: 10.24925/turjaf.v5i12.1660-1667.1736

36. Bilgili SF, Hess JB, Blake JP, Macklin KS, Saenmahayak B, Sibley JL. Influence of bedding material on footpad dermatitis in broiler chickens. J Appl Poultry Res. (2009) 18:583-9. doi: 10.3382/japr.2009-00023

37. Beagle EC, Fao R (Italy) ASD eng. Rice-Husk Conversion to Energy. (1978) Available online at: https://agris.fao.org/agris-search/search.do? recordID= XF2016016371 (accessed January 11, 2021).

38. Muthayya S, Sugimoto J, Montgomery S, Maberly G. An overview of global rice production, supply, trade, and consumption. Ann N Y Acad Sci. (2014) 1324:7-14. doi: $10.1111 /$ nyas. 12540

39. Mistry B. Properties and industrial applications of rice husk. From the Desk of Editors. Int J Eng Sci Comput. (2016) 6:2677-9.

40. Ahsan MB, Hossain Z. Use of Rice Husk Ash (RHA) as a sustainable cementitious material for concrete construction. In: Struble L, Tebaldi G, editors. Materials for Sustainable Infrastructure Sustainable Civil Infrastructures. Cham: Springer International Publishing) (2018). p. 197210. doi: 10.1007/978-3-319-61633-9_12

41. Abbas A, Ansumali S. Global potential of rice husk as a renewable feedstock for ethanol biofuel production. Bioenerg Res. (2010) 3:32834. doi: 10.1007/s12155-010-9088-0

42. Ranum P, Peña-Rosas JP, Garcia-Casal MN. Global maize production, utilization, and consumption. Ann N Y Acad Sci. (2014) 1312:10512. doi: $10.1111 /$ nyas. 12396

43. BoŽović I, Radosavljević M, Žilić S, Jovanović R. A genetic base of utilisation of maize cob as a valuable naturally renewable raw material. Genetika. (2004) 36:245-56. doi: 10.2298/GENSR0403245B

44. Cao Q, Xie K-C, Lv Y-K, Bao W-R. Process effects on activated carbon with large specific surface area from corn cob. Bioresour Technol. (2006) 97:110-5. doi: 10.1016/j.biortech.2005.02.026

45. Pinto J, Cruz D, Paiva A, Pereira S, Tavares P, Fernandes L, et al. Characterization of corn cob as a possible raw building material. Construc Build Mater. (2012) 34:28-33. doi: 10.1016/j.conbuildmat.2012.02.014 
46. Arun K, Ramanan MV. Experimental studies on gasification of corn cobs in a fixed bed system. J Chem Pharm Res. (2016) 8:667-76.

47. Menon V, Rao M. Trends in bioconversion of lignocellulose: biofuels, platform chemicals \& biorefinery concept. Prog Energy Combustion Sci. (2012) 38:522-50. doi: 10.1016/j.pecs.2012.02.002

48. United Nations Environment. Sand, Rarer than One Thinks: UNEP Global Environmental Alert Service (GEAS) - March 2014. (2014) Available online at: https://wedocs.unep.org/xmlui/handle/20.500.11822/8665 (accessed January 13, 2021)

49. Che J, Wang D, Liu H, Zhang Y. Mechanical properties of Desert Sand-Based Fiber Reinforced Concrete (DS-FRC). Appl Sci. (2019) 9:1857. doi: 10.3390/app9091857

50. Wang Y, Yan P, Han G, Wu W, Zhang R. Sand source and formation mechanism of riverine sand dunes: a case study in Xiangshui River, China. $J$ Arid Land. (2019) 11:525-36. doi: 10.1007/s40333-019-0102-x

51. Camara AY, Keita A, Li H, Keita SM. Effect of mining by rusal company on renewable natural resources in the prefecture of fria, Republic of Guinea. $J$ Environ Pollut Human Health. (2018) 6:7-19. doi: 10.12691/jephh-6-1-2

52. Fleury N, Lahaye M. Chemical and physico-chemical characterisation of fibres from Laminaria digitata (kombu breton): a physiological approach. J Sci Food Agric. (1991) 55:389-400. doi: 10.1002/jsfa.2740550307

53. Boulos NN, Greenfield H, Wills R. Water holding capacity of selected soluble and insoluble dietary fibre. Int J Food Propert. (2000) 3:21731. doi: 10.1080/10942910009524629

54. Melati RB, Schmatz AA, Pagnocca, FC, Contiero J, Brienzo M. Sugarcane Bagasse: Production, Composition, Properties, and Feedstock Potential. Available online at: https://repositorio.unesp.br/handle/11449/174692 (accessed December 11, 2018).

55. Teixeira AS, de Oliveira MC, Menezes JF, Gouvea BM, Teixeira SR, Gomes AR. Poultry litter of wood shavings and/or sugarcane bagasse: animal performance and bed quality. Revista Colombiana de Ciencias Pecuarias. (2015) 28:238-46. doi: 10.17533/udea.rccp.v28n3a4

56. Musa I, Sáidu L, Yunusa K, Abubakar UB, Wakawa AM. Poultry litter selection, management and utilization in Nigeria. Asian J Poultry Scis. (2012) 6:44-55. doi: 10.3923/ajpsaj.2012.44.55

57. Burke GB, Pescatore AJ, Cantor AH, Straw ML, Xiangbai H, Johnson TH. Newspaper as litter material and its effects on the performance of broilers1. $J$ Appl Poultry Res. (1993) 2:154-8. doi: 10.1093/japr/2.2.154

58. Lien RJ, Hess JB, Conner DE, Wood CW, Shelby RA. Peanut hulls as a litter source for broiler breeder replacement pullets. Poult Sci. (1998) 77:41-6. doi: 10.1093/ps/77.1.41

59. Caselli M, de Gennaro G, Saracino MR, Tutino M. Indoor contaminants from newspapers: VOCs emissions in newspaper stands. Environ Res. (2009) 109:149-57. doi: 10.1016/j.envres.2008.10.011

60. Zhou RX, Stanley R, Le M. Contamination of food with newspaper ink: an evidence-informed decision making (EIDM) case study of homemade dessert. Environ Health Rev. (2012) 55:63-9. doi: 10.5864/d2012-005

61. Mohammadi Torkashvand A, Alidoust M, Mahboub Khomami A. The reuse of peanut organic wastes as a growth medium for ornamental plants. Int $J$ Recycl Org Waste Agricult. (2015) 4:85-94. doi: 10.1007/s40093-015-0088-0

62. Maití RK, Wesche-Ebeling P. The Peanut (Arachis hypogaea) Crop. undefined. (2002) Available online at: https://www.semanticscholar.org/ paper/The-peanut-(Arachis-hypogaea)-crop-Mait\%C3\%AD-WescheEbeling/b371d6d3c6b329e8b5f225ea13c7e9d7c0d1d737 (accessed January 13, 2021).

63. USDA. Foreign Agricultural Service. (2016) Available online at: https://apps. fas.usda.gov/psdonline/ (accessed January 12, 2021).

64. Davis JP, Dean LL. Peanut composition, flavor and nutrition. Peanuts. (2016) 11:289-345. doi: 10.1016/B978-1-63067-038-2.00011-3

65. Hamm W, Hamilton RJ, Calliauw G, editors. Edible Oil Processing. 2nd ed. Malden, MA: Wiley-Blackwell (2013). doi: 10.1002/9781118535202

66. Kerr TJ, Windham WR, Woodward JH, Benner R. Chemical composition and in-vitro digestibility of thermochemically treated peanut hulls. J Sci Food Agric. (1986) 37:632-6. doi: 10.1002/jsfa.2740370706

67. Watts DB, Hess JB, Bilgili SF, Torbert HA, Sibley JL, Davis JD. Flue gas desulfurization gypsum: its effectiveness as an alternative bedding material for broiler production. J Appl Poultry Res. (2017) 26:509. doi: $10.3382 / \mathrm{japr} / \mathrm{pfw} 045$
68. Diarra SS, Neiubi S, Lesumairotorua J, Verau L. Evaluation of para grass (Urochloa mutica) as litter material for laying hens. Res Opin Animal Veterinary Sci. (2014) 4:560-3.

69. Grimes JL, Smithi J, Williams CM. Some alternative litter materials used for growing broilers and turkeys. World's Poultry Sci J. (2002) 58:51526. doi: 10.1079/WPS20020037

70. Roehrig KL. The physiological effects of dietary fiber-a review. Food Hydrocoll. (1988) 2:1-18. doi: 10.1016/S0268-005X(88)80033-X

71. Schneeman BO. Dietary fiber and gastrointestinal function. Nutrit Res. (1998) 18:625-32. doi: 10.1016/S0271-5317(98)00049-9

72. Coblentz WK, Turner JE, Scarbrough DA, Lesmeister KE, Johnson ZB, Kellogg DW, et al. Storage characteristics and nutritive value changes in bermudagrass hay as affected by moisture content and density of rectangular bales. Crop Sci. (2000) 40:1375-83. doi: 10.2135/cropsci2000.405 $1375 \mathrm{x}$

73. Turner JE, Coblentz WK, Scarbrough DA, Rhein RT, Coffey KP, Johnson $\mathrm{ZB}$, et al. Changes in nutritive value of tall fescue hay as affected by natural rainfall and moisture concentration at baling. Anim Feed Sci Technol. (2003) 109:47-63. doi: 10.1016/S0377-8401(03)00209-8

74. Foley KM. Chemical Properties, Physical Properties and Uses of The Andersons' Corncob Products. The Andersons, Cob Division, Processing Group (1978).

75. Koenig RT, Palmer MD, Jr FDM, Miller BE, Harrison JD. Chemical amendments and process controls to reduce ammonia volatilization during in-house composting. Compost Sci Util. (2005) 13:141-9. doi: 10.1080/1065657X.2005.10702231

76. Sheng J, Adeli A, Miles DM. Effects of N and P immobilizing agents on ammonia emissions and nutrient contents of broiler litter. JSM Environ Sci Ecol. (2015) 3:8.

77. Watts D, Runion B, Purswell J, Torbert A, Davis J. FGD gypsum litter effects on gaseous losses from a broiler house. Int J Poult Sci. (2020) 19:42-50. doi: 10.3923/ijps.2020.42.50

78. Weaver WD, Meijerhof R. The effect of different levels of relative humidity and air movement on litter conditions, ammonia levels, growth, and carcass quality for broiler chickens. Poult Sci. (1991) 70:74655. doi: 10.3382/ps.0700746

79. Reece FN, Lott BD, Deaton JW. Ammonia in the atmosphere during brooding affects performance of broiler chickens. Poult Sci. (1980) 59:4868. doi: $10.3382 /$ ps. 0590486

80. Deaton JW, Reece FN, Lott BD. Effect of atmospheric ammonia on pullets at point of lay. Poult Sci. (1984) 63:384-5. doi: 10.3382/ps.0630384

81. Miles DM, Branton SL, Lott BD. Atmospheric ammonia is detrimental to the performance of modern commercial broilers. Poult Sci. (2004) 83:16504. doi: $10.1093 / \mathrm{ps} / 83.10 .1650$

82. Kim WK, Anderson RC, Ratliff AL, Nisbet DJ, Ricke SC. Growth inhibition by nitrocompounds of selected uric acid-utilizing microorganisms isolated from poultry manure. J Environ Sci Health B. (2006) 41:97107. doi: $10.1080 / 03601230500234950$

83. Maheshwari S. Environmental impacts of poultry production. Poultry Fisheries Wildlife Sci. (2013) 1:1-2. doi: 10.4172/pfw. 1000101

84. Nagaraja KV, Emery DA, Jordan KA, Newman JA, Pomeroy BS. Scanning electron microscopic studies of adverse effects of ammonia on tracheal tissues of turkeys. Am J Vet Res. (1983) 44:1530-6.

85. Nagaraja K, Emery D, Jordan K, Sivanandan V, Newman JA, Pomeroy BS. Effect of ammonia on the quantitative clearance of Escherichia coli from lungs, air sacs, and livers of turkeys aerosol vaccinated against Escherichia coli. Am J Vet Res. (1984) 45:392-5.

86. Munir MT. Epidemiology and management strategies of Johne's disease in endemic situations. Res J Veterinary Practitioners. (2014) 2:8490. doi: 10.14737/journal.rjvp/2014/2.5.84.90

87. Park JH, Kim IH. Supplemental effect of probioticBacillus subtilis B2A on productivity, organ weight, intestinalSalmonella microflora, and breast meat quality of growing broiler chicks. Poult Sci. (2014) 93:20549. doi: 10.3382/ps.2013-03818

88. Sharma NK, Choct M, Wu S, Swick RA. Nutritional effects on odour emissions in broiler production. World's Poultry Sci J. (2017) 73:25780. doi: $10.1017 /$ /S0043933917000046 
89. Cabrera ML, Kissel DE, Hassan S, Rema JA, Cassity-Duffey K. Litter type and number of flocks affect sex hormones in broiler litter. J Environ Qual. (2018) 47:156-61. doi: 10.2134/jeq2017.08.0301

90. Meda B, Hassouna M, Aubert C, Robin P, Dourmad JY. Influence of rearing conditions and manure management practices on ammonia and greenhouse gas emissions from poultry houses. World's Poultry Sci J. (2011) 67:44156. doi: 10.1017/S0043933911000493

91. Monira KN, Islam MA, Alam MJ, Wahid MA. Effect of litter materials on broiler performance and evaluation of manureal value of used litter in late autumn. Asian-Austral J Anim Sci. (2003) 16:555-7. doi: 10.5713/ajas.2003.555

92. Toghyani M, Gheisari A, Modaresi M, Tabeidian SA, Toghyani M. Effect of different litter material on performance and behavior of broiler chickens. Appl Anim Behav Sci. (2010) 122:48-52. doi: 10.1016/j.applanim.2009.11.008

93. Munir MT, Belloncle C, Irle M, Federighi M. Wood-based litter in poultry production: a review. World's Poultry Sci J. (2019) 75:516. doi: 10.1017/S0043933918000909

94. Nowaczewski S, Rosiński A, Markiewicz M, Kontecka H. Performance, footpad dermatitis and haemoglobin saturation in broiler chickens kept on different types of litter. Archiv fur Geflugelkunde. (2011) 75:132-9.

95. Petek M, ÇIbIk R, YIldIz H, Sonat FA, Gezen SS, Orman A, et al. The influence of different lighting programs, stocking densities and litter amounts on the welfare and productivity traits of a commercial broiler line. Veterinarija ir Zootechnika. (2010) 36-43.

96. Skomorucha I, Muchacka R, Sosnówka-Czajka E, Herbut E. Response of broiler chickens from three genetic groups to different stocking densities. Ann Animal Sci. (2009) 9:175-84.

97. Uzum MH, Toplu HD. Effects of stocking density and feed restriction on performance, carcass, meat quality characteristics and some stress parameters in broilers under heat stress. Revue de Médecine Vétérinaire. (2013) 164:546-54.

98. Shao D, He J, Lu J, Wang Q, Chang L, Shi SR, et al. Effects of sawdust thickness on the growth performance, environmental condition, and welfare quality of yellow broilers. Poult Sci. (2015) 94:1-6. doi: 10.3382/ps/peu003

99. Jones FT, Wineland MJ, Parsons JT, Hagler WM. Degradation of aflatoxin by poultry litter. Poult Sci. (1996) 75:52-8. doi: 10.3382/ps.0750052

100. Tilley BJ, Barnes HJ, Scott R, Rives DV, Brewer CE, Gerig T, et al. Litter and commercial turkey strain influence on focal ulcerative dermatitis ("Breast Buttons”). J Appl Poultry Res. (1996) 5:39-50. doi: 10.1093/japr/5.1.39

101. Taherparvar G, Seidavi A, Asadpour L, Payan-Carreira R, Laudadio V, Tufarelli V. Effect of litter treatment on growth performance, intestinal development, and selected cecum microbiota in broiler chickens. Revista Brasileira de Zootecnia. (2016) 45:257-64. doi: 10.1590/S1806-92902016000500008

102. Burt CD, Cabrera ML, Rothrock MJ, Kissel DE. Flue-gas desulfurization gypsum effects on urea-degrading bacteria and ammonia volatilization from broiler litter. Poult Sci. (2017) 96:2676-83. doi: 10.3382/ps/pex044

103. Oliveira MC de, Almeida CV, Andrade DO, Rodrigues SMM. Teor de matéria seca, $\mathrm{pH}$ e amônia volatilizada da cama de frango tratada ou não com diferentes aditivos. $R$ Bras Zootec. (2003) 32:951-4. doi: 10.1590/S1516-35982003000400022

104. Sampaio MAPM, Schocken-Iturrino RP, Sampaio AAM, Berchielli SCP, Biondi A. Estudo da população microbiana e da liberação de amônia da cama de frangos tratada com gesso agrícola. Arq Bras Med Vet Zootec. (1999) 51:559-64. doi: 10.1590/S0102-09351999000600010

105. Grimes JL, Carter TA, Godwin JL. Use of a litter material made from cotton waste, gypsum, and old newsprint for rearing broiler chickens. Poult Sci. (2006) 85:563-8. doi: 10.1093/ps/85.3.563
106. Wyatt CL, Goodman TN. Research note: the utilization of recycled sheetrock (Refined Gypsum) as a litter material for broiler houses1. Poult Sci. (1992) 71:1572-6. doi: 10.3382/ps.0711572

107. Mijinyawa Y, Dlamini BJ. Livestock and poultry wastes management in Swaziland. Livestock Res Rural Dev. (2006) 18. Retrieved from: http://www. lrrd.org/lrrd18/6/miji18088.htm

108. Völkel I, Schmitz C, Moors E, Gauly M, Czerny C-P. Frequency of Salmonella detection in a broiler flock depending on different litter materials-a field study. Berl Munch Tierarztl Wochenschr. (2011) 124:71-7.

109. Hill GM. Peanut by-products fed to cattle. Vet Clin North Am Food Anim Pract. (2002) 18:295-315. doi: 10.1016/S0749-0720(02)00019-1

110. Ouhida I, Pérez JF, Piedrafita J, Gasa J. The effects of sepiolite in broiler chicken diets of high, medium and low viscosity. productive performance and nutritive value. Anim Feed Sci Technol. (2000) 85:18394. doi: 10.1016/S0377-8401(00)00148-6

111. Montagne L, Pluske JR, Hampson DJ. A review of interactions between dietary fibre and the intestinal mucosa, and their consequences on digestive health in young non-ruminant animals. Anim Feed Sci Technol. (2003) 108:95-117. doi: 10.1016/S0377-8401(03)00163-9

112. Dikeman CL, Jr GCF. Viscosity as related to dietary fiber: a review. Crit Rev Food Sci Nutr. (2006) 46:649-63. doi: 10.1080/10408390500511862

113. Schøyen HF, Hetland H, Rouvinen-Watt K, Skrede A. Growth performance and ileal and total tract amino acid digestibility in broiler chickens fed diets containing bacterial protein produced on natural gas. Poult Sci. (2007) 86:87-93. doi: $10.1093 / \mathrm{ps} / 86.1 .87$

114. Wang L, Newman RK, Newman CW, Hofer PJ. Barley beta-glucans alter intestinal viscosity and reduce plasma cholesterol concentrations in chicks. J Nutr. (1992) 122:2292-7. doi: 10.1093/jn/122.11.2292

115. Jha R, Fouhse JM, Tiwari UP, Li L, Willing BP. Dietary fibre and intestinal health of monogastric animals. Front Veterinary Sci. (2019) 6:48. doi: $10.3389 /$ fvets. 2019.00048

116. Diarra S, Anand S. Impact of commercial feed dilution with copra meal or cassava leaf meal and enzyme supplementation on broiler performance. Poult Sci. (2020) 99:5867-73. doi: 10.1016/j.psj.2020.08.028

117. Ahmad T, Sarwar M. Dietary electrolyte balance: implications in heat stressed broilers. World s Poultry Sci J. (2006) 62:63853. doi: 10.1017/S0043933906001188

118. Atapattu NSBM, Wickramasinghe KP. The use of refused tea as litter material for broiler chickens. Poult Sci. (2007) 86:968-72. doi: 10.1093/ps/86.5.968

Conflict of Interest: The authors declare that the research was conducted in the absence of any commercial or financial relationships that could be construed as a potential conflict of interest.

Publisher's Note: All claims expressed in this article are solely those of the authors and do not necessarily represent those of their affiliated organizations, or those of the publisher, the editors and the reviewers. Any product that may be evaluated in this article, or claim that may be made by its manufacturer, is not guaranteed or endorsed by the publisher.

Copyright (C) 2021 Diarra, Lameta, Amosa and Anand. This is an open-access article distributed under the terms of the Creative Commons Attribution License (CC BY). The use, distribution or reproduction in other forums is permitted, provided the original author(s) and the copyright owner(s) are credited and that the original publication in this journal is cited, in accordance with accepted academic practice. No use, distribution or reproduction is permitted which does not comply with these terms. 